\title{
Bilimsel Bir Makale Nasıl Yazılır ve Yayımlanır?
} How to Write and Publish a Scientific Article?

\author{
Mahmut Çivilibal \\ Sağlık Bakanlığı Haseki Eğitim ve Araştırma Hastanesi, Çocuk Kliniği, istanbul, Türkiye
}

\section{Özet}

Tıp bilimi insanın olduğu her yerde ve her dönemde vazgeçilemez bir bilim dalı ve bir meslektir. Bu disiplin, bilimsel araştırmalarla ve yayınlarla gelişir. Bu sunumun amacı, bilimsel makale yazmanın inceliklerini ve püf noktalarını vurgulamaktır. (Haseki Tıp Bülteni 2013; 51: 85-8)

Anahtar Kelimeler: Araştırma, makale yazma, tıp bilimi

\begin{abstract}
Medical science is an essential science discipline and a profession at anytime and anywhere in the existence of human being. This discipline develops with scientific researches and publications. The purpose of this presentation was to emphasize the subtleties and tricks of article writing. (The Medical Bulletin of Haseki 2013; 51: 85-8)
\end{abstract}

Key Words: Research, article writing, medical science

\section{Giriş}

Tıp bilimi ve diğer tüm pozitif bilimler yapılan araştırmalarla gelişir. Bu araştırmaların sonuçlarının ve ender görülen olgu örneklerinin paylaşımı bilimsel dergilerde yayımlanan makaleler yoluyla olur (1).

Bilimsel makale yapmanın temelde dört ana nedeni vardır: bilime katkıda bulunmak, araştırma yapma hevesi, tez yazma gibi zorunlu nedenler ve akademik yükselme. Ayrıca, son yıllarda ülkemizde uygulanan performans yönetmenliği gereği sağlık çalışanlarına ek ödeme yapılması ve buna paralel daha fazla para kazanma isteği yayın yapmanın ülkemize özgü diğer bir nedenidir (2).

\section{Genel kurallar}

1) Makalenin uzunluğu: Gönderilecek derginin yazım kurallarına göre değişmekle birlikte, 12 punto ve çift aralıklı yazımda olgu sunumları A4 sayfası olarak 7-8 sayfayı, araştırma makaleleri 15-16 sayfayı geçmemelidir.

2) Makalenin bölümleri: Ayrıntıları aşağıda belirtilen; başlık sayfası, özet, giriş, gereç ve yöntem, bulgular, tartışma ve kaynaklar bölümlerinden oluşur.

3) Doğru zamanın kullanılması: Makalede yer alan klasik bilgiler ile tablo ve şekillerin sunumunda geniş zaman (simple present), yöntem ve sonuçların tarifi ile makale içinde bir referansa ilk yazarın adıyla atıfta bulunulmasında geçmiş zaman (simple past) kullanılır. İngilizce makaleler için örnekler; "Transplantation is the preferred treatment modality for ESRD", "Table-1 shows that the ........", "We retrospectively analyzed the incidence of ........", "The mean age of the patients in group A was ....." "Xxxxxx et al. reported that ....." (3).

4) Gereksiz kelime ve cümlelerden kaçınılması: Okuyucuyu yoran ve cümle içinden çıkarıldığında cümlenin anlamının değişmediği gereksiz ifadelere yer verilmemelidir. Örneğin, "Kan basıncı ölçümü çocuklarda rutin fizik muayenenin bir parçasıdır." cümlesinde rutin kelimesi gereksizdir. Türkçe veya İngilizce bir cümleye "Tartışmaya gelindiğinde ...." "We come to the conclusion that.........." gibi ifadelerle başlamanın makaleye olumlu bir katkısı olmayacaktır.

5) Dilin doğru kullanımı: Gerek Türkçe, gerekse Ingilizce yazımlarda zaman, gramer ve imla kurallarına dikkat edilmelidir. Özellikle İngilizce yazılan bir makalenin dergiye gönderilmeden önce Ingilizceyi ana dili gibi okuyup yazabilen birilerine kontrol ettirilmesi makalenin yayınlanabilme olasılığını artıır (3).

\section{Kapak yazısı}

Bir makale dergiye gönderilirken, nezaket gereği ve sözleşme beyanı niteliğinde bir mektupla gönderilmelidir (4). Aşağıda Türkçe ve İngilizce birer örnek verilmiştir.
Yazışma Adresi/Address for Correspondence: Mahmut Çivilibal

Haseki Eğitim ve Araştırma Hastanesi, Çocuk Kliniği, İstanbul, Türkiye Tel.: +902125294400 E-posta: drcivilibal@hotmail.com

Geliş Tarihi/Received: 31 Mayıs 2013 Kabul Tarihi/Accepted: 31 Mayıs 2013
The Medical Bulletin of Haseki Training and Research Hospital, published by Galenos Publishing. Haseki Tıp Bülteni,

Galenos Yayınevi tarafından basılmıştır. 


\section{Kapak yazısı (Türkçe) \\ Sayın Editör}

........başlıklı makalemizi ........isimli derginize yayımlanmak amacıyla değerlendirilmesi için göndermiş bulunmaktayız. Bu makale daha önce herhangi bir dergide yayımlanmamıştır veya halen yayımlanmak amacıyla herhangi bir dergide değerlendirmede değildir. Makale tüm yazarlar tarafından okunmuş ve onaylanmıştır.

Saygılarımla

Sorumlu araştırmacının adı ve iletişim bilgileri

\section{Kapak Yazısı Örneği (İngilizce) \\ Dear Editor,}

We hereby submit our manuscript entitled "..........." to be considered for publication in .................. This manuscript has not been published previously in whole or part, except in an abstract form, and has been read and approved by all authors.

Sincerely yours,

\section{Makalenin Ana Bölümleri}

1) IIlk sayfa (Başılı sayfası): Bu sayfada sırasıyla; başlık (Ingilizce/Türkçe), kısa başlık, yazarlar listesi, kurumlar ve sorumlu yazarın (correspondig author) iletişim bilgileri yer alır. Ayrıca ilgili dergi istiyorsa, anahtar kelimeler, çıkar çatışmasının (conflict of interest) ve kongrede sunulmuşsa bunun belirtilmesi gerekir. Başlık binlerce kişinin makaleyi okumaya devam edip etmeyeceğini göstermesi açısından son derece önemlidir. Bu nedenle dikkatle seçilmeli, basit, kısa ve ilgi çekici olmalıdır $(4,5)$.

2) Özet: Öncelikli veya bazen yalnızca okunan tek bölüm olması açısından çok önemlidir. Özet makaleyi temsil etmeli, 150 - 300 kelime arasında olmalı, kısaltma, referans, şekil, tablo ve atıf (citation) içermemelidir. Dergilerin yazım kurallarına bağlı olarak özetler yapılandırımış (structured) veya yapılandırılmamış (unstructured) türde olabilir. Yapılandırımış özetlerde, amaç, metot, bulgular ve sonuç başlıkları ile başlayan 4 ayrı paragraf yer alırken; yapılandırılmamış olanlarda bu alt başlıklar yer almaz ve tek paragrafta sunulur (6).

3) Ana metin: Giriş, yöntem, bulgular ve tartışma olmak üzere dört alt bölümden oluşur (4-6).

a) Giriş (Introduction): Makalenin odaklandığı ve konuyu özetleyerek tanıtan bölümdür. Çalışmanın gerekli olduğuna dikkat çekilen bu bölüm, kısa, genel, abartısız, dikkat çekici, hakemi uyaran, ancak kızdırmayan ve okuyucuyu kavrayan nitelikte olmalıdır. Giriş bölümünde amaç tam olarak aktarılmalı, konuyu vurgulayan önceki çalışmalar tanımlanmalı, çalışılacak hipotez ve çıkacak sonuçların önemi kısa ve öz olarak anlatılmalıdır. Bu bölümün sonunda araştırmanın niçin yapıldığı (amacı) çok net olarak ifade edilmelidir (4). b) Gereç ve Yöntem (Material and Methods): Araştırmanın planlama aşamasında yazılması gereken ve buna göre araştırmanın yapıldığı bölümdür. Çalışmanın kurgusu (ileriye dönük, kesitsel, geriye dönük, kontrollü vb.), araştırma materyali (hastalar veya deney hayvanları), çalışmaya alınma ve dışlanma kriterleri, varsa kullanılan ilaçlar veya kimyasal maddeler, analizlerde kullanılan yöntemler, araçlar ve işlemler açık bir şekilde yazılmalıdır. Etik kurul onayları ve kullanılan istatistiksel yöntemler bu bölümde yer almalıdır $(4,5)$.

c) Bulgular (Results): Girişte belirlenen veya çözümü aranan sorunları yanıtlayan, çalışma sonucunda ulaşılan verileri anlaşılır ve etkili bir şekilde ortaya koyan, hoşa giden veya gitmeyen verileri objektif olarak sunan bölümdür. Burada yalnızca bulgular verilir; hiçbir yorum yer almaz. Küçük sayılarda yüzde (\%) yerine mutlak sayı verilir. Ondalık sayılar gereğinden fazla uzatılmaz (örneğin, yaş ortalaması: 25,731 yerine 25,7$)(6)$.

d) Tartışma: Bu bölümde tipik sıralama; pozitif, nötral, negatif ve pozitif şeklinde olmalıdır (4-6).

i. Pozitif: Başlangıçtaki pozitif bölümde, ana bulgular vurgulanır ve sonuçlar değerlendirilir. Önceki bölümler (giriş, yöntem, bulgular) tekrarlanmaz. Bulgular bölümünde verilmeyen hiçbir veri ilk defa tartışmada geçmemelidir. Bulunan sonuçlar bir mantık çerçevesinde tartışılır. Tartışma pozitif yöne çekilmeye çalışılır ve negatifler pozitiflerin içine sıkıştırılır.

ii. Nötral: Bu bölümde, sunulan çalışma diğer çalışmalar ile karşılaştırılır. Benzerlik ve farklılıklara yorumlar getirilir. Yalnızca destekleyenler değil, aksi yönde olanlar da kullanılır. Bulguların içerdiği yenilikler vurgulanır.

iii. Negatif: Çalışmanın zayıf yönlerin anlatıldığı ve buna rağmen çalışmaya niçin inanıldığının anlatıldığı bölümdür. Zayıf yönler kurgu yanlışlığı, seçim ikilemi, karıştırıcı faktörler, örneklem küçüklüğü, bazı parametrelerin tayin edilememesi, takip dışı kalan hastalar, veri eksikliği vb. şeklinde olabilir.

iv. Pozitif: Tartışmanın sonunda yer alacak pozitif bölümde ise, çalışmanın güçlü taraflarının altı çizilir. Varılan sonuçlar ve ileride yapılabilecek çalışmalara yönelik öneriler ile bitirilir. Böylelikle, önceki çalışmalardan farklı olarak neler yapıldı, bulguların verdiği mesaj nedir, bu çalışma ne işe yaradı, bu probleme daha fazla açıklık getirmek veya çözmek için ne tür çalışmalar yapılmalı gibi sorulara yanıtlar bulunmalıdır.

Ayrıca tartışma bölümünde gereksiz iddialardan sakınmalı (dünyanın ilk çalışması, en büyük veritabanı gibi), diğer çalışmaları doğrudan eleştirmemeli (eleştirdiğiniz araştırıcı sizin hakeminiz olabilir), aşırı spekülasyonlardan kaçınmalı ve çalışma bulguları dışına taşan sonuçlara varılmamalıdır (7). 
e) Teşekkür bölümü: Araştırmanın yapılması veya makalenin yazılmasında (gramer ve dil açısından kontrol, istatistik veya parasal katkı gibi) yardımı olan ancak yazarlar listesinde yer almayan kişi veya kurumlara teşekkür edilen bölümdür.

f) Kaynaklar: Kaynaklar gönderilecek derginin yazım kurallarına uygun şekilde yazılır ve yazı içinde geçiş sırasına göre numaralandırılır. Kaynaklar konu ile doğrudan ilgili, derginin yazım kurallarında belirtilen sayıyı geçmeyen, makale içi kaynak numaraları ile tutarlı, yalnızca güncel kaynakları değil, o konuda yapıımış en önemli çalışmaları da (eski tarihli olsa da) içeren, doğru okunan ve bir diğer kaynaktan doğrudan alıntı yapılmayan makalelerden seçilmelidir (4-6).

g) Tablolar ve şekiller: Veri sunumunda açıklık ve etkinlik sağlar. Basit, kolay ve anlaşılır olmalıdır. Her tablo ayrı birer Word dosyası, her şekil ayrı bir resim dosyası (JPEG veya TIF) olarak hazırlanır. Altında açıklayıcı bilgiler ve kısaltmalar verilebilir. Tablo ve şekillerde yer alan bilgiler metin içinde tekrarlanmaz, ilgili tablo veya şekile ait kısa açıklamalar bulgular bölümünde yazıı ır ("..... sonuçlarımız Tablo 2'de ve Şekil 3'te sunulmuştur" gibi). Tablo başlıkları tablonun üstüne, şekil başlıkları şeklin altına yazılır. Tablolarda enine çizgiler kullanılmaz (6).

\section{Makalenin Gönderileceği Derginin Seçimi}

Dergiler temel olarak ulusal ve uluslararası dergiler olarak iki ana gruptur. Ulusal dergiler, hakemli veya hakemsiz, Türk Tıp Dizini'nde olan veya olmayan dergilerdir. Hakemli, Türk Tıp Dizini'nde yer alan ve çeşitli ulusal veya uluslararası indekslerde yer alan dergiler tercih edilmelidir. Uluslararası dergiler ise, Science Citation Index (SCl) veya SCl-Expanded'de yer alan ve yer almayan dergiler olarak nitelendirilir (5). Akademik yükselmelerde $\mathrm{SCl}$ veya $\mathrm{SCl}$ Expanded kapsamındaki dergilerde basılmış makaleler tercih sebebidir.

Türk Tıp Dizini'nde yer alan ulusal dergilerin "Ulusal Katkı Değeri" ve uluslararası dergilerin "Etki Değeri (Impact Factor)" adı verilen ve bir derginin bilimsel alandaki değerini gösteren ölçekleri vardır. Ulusal Katkı Değeri; Türkiye Atıf Dizini veri tabanına kayıtlı bir derginin önceki iki yılda veri tabanına kayıtlı diğer dergilerden aldığı atıf sayısının tarama yapılan yılda derginin yayımladığı toplam makale sayısına bölünmesiyle hesaplanır. "Impact Factor" de benzer şekilde, $\mathrm{SCl}$ veya SCI-Expanded veri tabanına kayıtlı bir derginin önceki iki yılda aynı veri tabanına kayıtlı diğer dergilerden aldığı atıf sayısının tarama yapılan yılda derginin yayımladığı toplam makale sayısına bölünmesiyle hesaplanır. Bu nedenlerle dergi seçiminde, Ulusal Katkı Değeri ve Impact Factor önem arz eder; başka bir anlatımla veya kaba deyimle, derginin büyüklüğünü ifade eder (8).

Dergilerde yer alan makaleler; derleme, araştırma makalesi, olgu sunumu, editöre mektup, ayın olgusu, görüntüler (imaging) şeklinde olabilir. Bu nedenle dergi seçiminde makalenin türüne göre de dergi seçimi gerekebilir. Çünkü her dergi yukarıda belirtilen tüm makale şekillerine yer vermemektedir. Dergi seçiminde öncelikle derginin web sayfası ziyaret edilerek "hakkında", "yazım kuralları" ve "yayın kurulu" bölümleri ayrıntılı olarak okunmalıdır. Bir başka anlatımla, derginin mutfağı iyi incelenmelidir.

Dergi seçiminde bir diğer önemli ölçüt, derginin hangi tıp alanında ve hangi konularda yayın kabul ettiğidir. Bazı dergiler genel tıp konularına yer veren geniş yelpazesi olan dergiler iken (örnek: Haseki Tıp Bülteni), bazı dergiler belli branşlardaki çalışmalara (örnek: Pediatric Nephrology) yer verir. Hatta sadece bir konuya yönelmiş dergiler de (örneğin: Cancer Cell) vardır (4-6).

\section{Hakem Seçimi}

Günümüzde dergilerin tamamına yakını makaleleri "online" olarak kabul etmektedir. Bu gönderim esnasında birçok dergi tercih edilen ve tercih edilmeyen hakem seçimine olanak sağlamaktadır. Hakem seçimine dergi editörü ve editör yardımcıları son kararı vermekle birlikte, yaptığınız hakem seçimini de önemsemektedirler. Bu nedenle hakem seçiminde konuyla yakından ilişkili olan, bu konuda yayınları bulunan ve çalışmanızda bu kişilerin araştırmalarına da yer verdiğiniz yazarlar olması çok önemlidir (4-6).

Hakem denildiğinde genç yaştaki araştırmacılarda genellikle yanlış bir algının olduğu görülür. Genellikle sizden daha yaşlı, daha yorgun, daha yoğun, belki de yazınızı uygunsuz bir zaman diliminde (iş günü sonunda, hafta sonunda, bazen de gece yarısı/uykulu olarak) okuyan ve en olmayacak detaylara kafasını takan, titiz, sinirli kişilermiş gibi algılanır. Elbette ki ciddi dergilerin hakemleri işini titizlikle yapan, konusunda söz sahibi ve bu nedenle hakemliği profesyonel bir şekilde yapan meslektaşlarımız veya hocalarımızdır.

Editör ve hakemlerden gelen eleştiriler ve kaygılar özenli bir şekilde incelenmelidir. Önemsiz olduğu düşünülen noktalar olabilir, ancak bunlar kesinlikle gözardı edilmemelidir. Hakemin önerisini kabul etmemek için çok geçerli nedenler olmalıdır. Revizyonlar çok uzun ve çok ayrıntılı yazıımamalıdır. Hakem ve editörler, site edilmekten çok mutlu olurlar; onları bu yolla mutlu etmek lehinize olacaktır $(7,9)$.

Uygun şekilde yazıımış her makalenin kabul göreceği bir dergi mutlaka vardır. Yazınızın kabul edilmemesi ayıplanılacak, saklanılacak, utanılacak veya çekinilecek bir durum değildir. Bir makale bazı nedenlerle herhangi bir dergi tarafından reddedilmişse, varsa hakem eleştirilerine uygun şekilde yeniden düzenlenmeli ve başka bir dergiye gönderilmelidir (7). 
Sonuç olarak; bilimsel çalışma yapılması ve yazııması zor, sabır gerektiren, ancak zevkli ve kutsal bir uğraştır. Makale yazımının her aşamasında dikkat edilecek kritik noktalar yazının kabul şansını artırır. Makalenin reddedilmiş olması dünyanın sonu değildir. Her makaleyi kabul edecek bir dergi mutlaka vardır.

Muhtemelen, bu konuda genç yazarlara verilecek en önemli tavsiyelerden biri konularıyla ilgili mümkün olduğunca çok sayıda yayınlanmış bilimsel makale okumalarıdır. Ne var ki, çok saygın yazarlardan, akıcı dilden, v.b. birçok unsurdan bir şekilde etkilenmek bu işin bir nevi handikapıdır. Benzer cümlelerin kullanımı, bilgiye kolay erişim çağında artık birçok dergi editörleri tarafından kolayca tespit edilebilmektedir. Özgün çalışmalar, özgün tasarlanmış ifadeler mesleki hayata da değer katacaktır.

\section{Kaynaklar}

1. Kapoor S, Sikka P, Saxena K. Publication of research article: an art or science? Ann Med Health Sci Res. 2013;3:96-8.

2. Türkiye Kamu Hastaneleri Kurumuna Bağlı Sağlık Tesislerinde Görevli Personele Ek Ödeme Yapılmasına Dair Yönetmelik. 14 Şubat 2013 Tarihli ve 28559 Sayılı Resmî Gazete.

3. Davis AJ, Tschudin V. Publishing in English-language journals. Nurs Ethics. 2007;14:425-30.

4. Dixon N. Writing for publication-a guide for new authors. Int J Qual Health Care. 2001;13:417-21.

5. Szklo M. Quality of scientific articles. Rev Saude Publica. 2006;40:30-5.

6. Veness M. Strategies to successfully publish your first manuscript. J Med Imaging Radiat Oncol. 2010;54:395-400.

7. Pierson DJ. The top 10 reasons why manuscripts are not accepted for publication. Respir Care. 2004;49:1246-52.

8. Triaridis S, Kyrgidis A. Peer review and journal impact factor: the two pillars of contemporary medical publishing. Hippokratia. 2010;14(Suppl 1):5-12.

9. Callaham ML. Journal policy on ethics in scientific publication. Ann Emerg Med. 2003;41:82-9. 